\title{
Model Pembelajaran Problem Based Instruction terhadap Kemampuan Komunikasi Matematis dan Kemampuan Berpikir Kreatif Siswa
}

\author{
Indah Febriani $^{1}$, Kurnia Islamy ${ }^{2}$, Rika Wahyuni ${ }^{3, *}$, Nindy Citroresmi Prihartiningtyas ${ }^{4}$ \\ STKIP Singkawang, Singkawang, Indonesia \\ indah.febriani2001@gmail.com ${ }^{1}$, kurniaislamy@gmail.com², rikawahyuni142@gmail.com², \\ nindy.citroresmi@gmail.com ${ }^{4}$ \\ ${ }^{*}$ Corresponding author
}

\section{Kata Kunci:}

Problem Based Instruction;

Kemampuan Komunikasi

Matematis; Kemampuan

Berpikir Kreatif; Motivasi

Belajar

\begin{abstract}
ABSTRAK
Penelitian ini bertujuan untuk menguji perbedaan kemampuan komunikasi matematis dan kemampuan berpikir kreatif yang diberikan dengan model pembelajaran Problem Based Iinstruction (PBI) dan model langsung, mengidentifikasi pengaruh model pembelajaran PBI terhadap kemampuan komunikasi matematis dan berpikir kreatif, dan mengindentifikasi motivasi siswa terhadap model pembelajaran PBI terhadap kemampuan komunikasi matematis dan kemampuan berpikir kreatif. Jenis penelitian ini adalah quasi eksperimental design dengan rancangan nonequivalent posstest-only control group design. Intsrumen yang digunakan dalam penelitian ini adalah tes kemampuan komunikasi matematis dan kemampuan berpikir kreatif, angket motivasi belajar siswa. Teknik analisis data menggunakan ujit independent, effect size, dan skala Likert. Berdasarkan hasil analisis data disimpulkan bahwa kemampuan komunikasi matematis dan kemampuan berpikir kreatif antara yang diajarkan melalui model PBI dengan model pembelajaran langsung berbeda, model PBI memberikan pengaruh yang besar terhadap kemampuan komunikasi matematis dan kemampuan berpikir kreatif, dan motivasi belajar siswa tinggi melalui model pembelajaran PBI.
\end{abstract}

\section{PENDAHULUAN}

Matematika adalah salah satu bidang studi yang diajarkan di Sekolah. Baik Sekolah dasar, Sekolah Mengengah Pertama dan Sekolah Menengah Umum. Matematika dalam pembelajaran adalah belajar tentang hubungan antara konsep dan struktur matematika yang dimana pembelajarannya para siswa dibiasakan untuk memperoleh pemahaman melalui pengalaman yang melibatkan siswa secara aktif mengkonstruksi pengetahuan matematika. Penguasaan terhadap bidang studi matematika merupakan suatu kewajiban, karena matematika sebagai pintu masuk menguasai sains dan teknologi yang berkembang pesat, dengan belajar matematika orang dapat mngembangkan kemampuan berpikir secara matematis, logis, kritis dan kreatif yang sungguh dibutuhkan dalam kehidupan (Noviarti, Utami, dan Prihatiningtyas, 2020). Menurut Jayanti \& Wiratomo (2017), pembelajaran matematika 
merupakan proses aktif dan konstruktif dimana peserta didik terlibat di dalamnya sehingga paham dan mampu menyelesaikan permasalahan yang dihadapi.

Komunikasi matematis yaitu kemampuan untuk mengekspresikan ide-ide matematika secara koheren kepada teman, guru, dan lainnya melalui bahasa lisan tulisan (Soraya, Rosmaiyadi, \& Wahyuni, 2021). Kemudian Habibah (2016) mengemukakan komunikasi dapat membantu pembelajaran siswa tentang konsep matematika baru ketika mereka memerankan situasi menggambar, menggunakan objek, memberikan laporan dan penjelasan verbal. Hal ini terjadi karena salah satu unsur dari matematika adalah ilmu logika yang mampu mengembangkan kemampuan berpikir siswa. Selain kemampuan komunikasi matematis menurut NCTM kemampuan yang sama pentingnya dengan kemampuan komunikasi matematis adalah kemampuan berpikir kreatif. Menurut Firman, Mariyam, dan Wahyuni (2020), kemampuan berpikir kreatif adalah kemampuan menemukan banyak kemungkinan jawaban terhadap suatu masalah, dimana penekanannya adalah pada kuantitas, ketepat gunaan, dan keragaman jawaban. Kemampuan berpikir kreatif matematis merupakan kemampuan untuk menghasilkan solusi bervariasi yang bersifat baru terhadap masalah matematika yang terbuka. Selanjutnya menurut Saputra (2018), berpikir tersebut melibatkan sintesis ide-ide, membangun ide-ide baru dan menentukan efektivitasnya.

Berdasarkan hal tersebut diatas, maka akan dilakukan pengkajian tentang kemampuan komunikasi matematis dan kemampuan berpikir kreatif matematis siswa. Saat peneliti melakukan prariset di SMP Negeri 1 Singkawang banyak siswa yang masih bingung dengan penyampaian bahasa/simbol matika dan menghasilkan gagasan baru dalam menyelesaikan masalah dalam kehidupan sehari-hari. Hal ini dapat dilihat dari hasil prariset berikut ini. Pada saat prariset yang dilakukan di SMP Negeri 1 Singkawang pada tahun ajaran 2019/2020 dimana kemampuan komunikasi matematis siswa dan berpikir kreatif siswa masih rendah, dari hasil jawaban siswa menunjukkan bahwa siswa sudah bisa mengubah soal kedalam bentuk matematika atau membuat model matematika pada soal. Dari permasalahan tersebut dapat disimpulkan bahwa kemampuan komunikasi matematis dan berpikir kreatif matematis siswa masih rendah. Rendahnya motivasi yang membuat belajar siswa menurun.

Menurut Sefrinal (2019), motivasi adalah sebuah dorongan, hasrat ataupun minat yang begitu besar di dalam diri , untuk mencapai suatu keinginan. Oleh karena itu dalam proses belajar mengajar motivasi siswa juga perlu, agar situasi belajar mengajar berjalan dengan kondusif dan berjalan sesuai tujuan yang ingin dicapai. Rendahnya motivasi dalam pembelajaran matematika diduga model pembelajaran pendidik yang kurang tepat dalam proses pembelajaran. Salah satu materi yang masih sering mengalami ketidak tuntasan yaitu materi Bangun Ruang Sisi Datar. Bangun Ruang Sisi Datar adalah suatu bangun tiga dimensi yang memiliki ruang/volume/isi dan juga sisi-sisi yang membatasinya. Namun kenyataannya siswa mengalami kesulitan, salah satu hambatan dalam materi bangun ruang sisi datar yaitu siswa terpaku pada satu metode yang dimana siswa lebih terpaku pada gambar.

Untuk mendukung kemampuan komunikasi matematis dan kemampuan berpikir kreatif siswa pada proses pembelajaran maka dituntut seorang pengajar pada proses pembelajaran dengan pengunaan metode, model, atau pendekatan pembelajaran yang tepat. Model pembelajaran yang diperkirakan berkaitan untuk pembelajaran matematika dalam rangka menumbuhkan pembentukan komunikasi matematis dan berpikir kreatif matematis siswa antara lain model pembelajaran Problem Based Instruction (PBI).

Model PBI dilandasi oleh teori belajar konstruktivis. Pada model ini pembelajaran dimulai dengan menyajikan permasalahan nyata yang penyelesaiannya membutuhkan kerja sama di antara siswasiswa. Dalam model pembelajaran ini pendidik memandu siswa menguraikan rencana pemecahan masalah menjadi tahap-tahap kegiatan; guru memberi contoh mengenai penggunaan keterampilan dan strategi yang dibutuhkan supaya tugas-tugas tersebut dapat diselesaikan (Novriansyah, Harlin, \& Syofii, 2018). 
Penelitian ini berbeda dengan hasil kajian penelitian oleh Arif \& Herlina (2018) yang berjudul "Penerapan Pendekatan Problem Based Instruction (PBI) Berorientasi Model Pembelajaran Think Pair-Share (TPS) dalam Upaya Meningkatkan Motivasi dan Hasil Belajar Mahasiswa Pada Mata Kuliah Evolusi”. Dalam penelitiannya dapat dilihat bahwa model pembelajaran yang diterapkan hanya meningkatkan satu kemampuan. Sedangkan dalam penelitian ini model pembelajaran yang digunakan dapat meningkatkan dua kemampuan. Penelitian ini juga bermaksud memudahkan penjelasan kepada guru tentang model pembelajaran PBI.

Berdasarkan latar belakang tersebut, penelitian ini bertujuan untuk menguji perbedaan kemampuan komunikasi matematis dan kemampuan berpikir kreatif yang diberikan dengan model pembelajaran PBI dan model langsung, mengidentifikasi pengaruh model pembelajaran PBI terhadap kemampuan komunikasi matematis dan berpikir kreatif, serta mengindentifikasi motivasi siswa terhadap model pembelajaran PBI terhadap kemampuan komunikasi matematis dan kemampuan berpikir kreatif.

\section{METODE PENELITIAN}

Jenis penelitian yang dilakukan adalah quasi experimental design dengan rancangan nonequivalent posstest-only control group design. Adanya penggunaan rancangan nonequivalent posstest-only control group design dikarenakan fokus dalam penelitian ini adalah untuk mengetahui kemampuan komunikasi matematis dan kemampuan berpikir kreatif siswa berdasarkan hasil posstest pada kelas eksperimen setelah dikenakan model PBI dan pada kelas kontrol dikenakan model pembelajaran langsung. Adapun rancangan penelitian ini disajikan pada Gambar 1.

$$
\begin{array}{|lll|}
\hline \mathbf{R}_{1} & \mathbf{X}_{1} & \mathbf{O}_{1} \\
\mathbf{R}_{2} & \mathbf{X}_{2} & \mathbf{O}_{2} \\
\hline
\end{array}
$$

Gambar 1. Rancangan Penelitian

(Sugiyono, 2017)

Keterangan:

$\mathrm{R}_{1}=$ kelas eksperimen

$\mathrm{R}_{2}=$ kelas kontrol

$\mathrm{O}_{1}=$ post-test pada kelompok kelas eksperimen

$\mathrm{O}_{2}=$ post-test pada kelompok kelas kontrol

$\mathrm{X}_{1}=$ perlakuan (treatment) dengan Problem Based Instruction

$\mathrm{X}_{2}=$ perlakuan dengan pembelajaran langsung

Penelitian ini dilaksanakan di SMP Negeri 1 Singkawang kelas VIII yang beralamat di kelurahan melayu Kecamatan Singkawang Tengah. Populasi dalam penelitian ini adalah siswa kelas VIII SMP Negeri 1 Singkawang yang berjumlah 6 kelas, dan sampel dalam penelitian ini adalah sebanyak 2 kelas dari jumlah kelas yang ada yaitu kelas VIII E dan kelas VIII F.

Teknik pengumpulan data yang digunakan dalam penelitian ini adalah teknik tes dan teknik komunikasi tak langsung dengan instrumen pengumpulan data tes kemampuan komunikasi matematis dan kemampuan berpikir kreatif, serta angket motivasi belajar. Teknik analisis data yang digunakan dalam penelitian ini yaitu menggunakan menggunakan uji-t independent, effect size, dan skala Likert.

\section{HASIL DAN PEMBAHASAN}

\section{Kemampuan Komunikasi Matematis}

Data hasil belajar diperoleh dari kelas eksperimen dan kelas kontrol yang masing-masing kelas berjumlah 25 siswa. Kemudian kedua kelas diberikan soal post-test. Dari hasil post-test dihitung dan diperoleh hasil pada Tabel 1. 
Tabel 1. Data Hasil Post-Test Kemampuan Komunikasi Matematis

\begin{tabular}{cccccc}
\hline $\begin{array}{c}\text { Kelompok } \\
\text { kelas }\end{array}$ & $\boldsymbol{N}$ & $\overline{\boldsymbol{X}}$ & $\boldsymbol{S}^{\mathbf{2}}$ & $\begin{array}{c}\text { Nilai } \\
\text { Terendah }\end{array}$ & $\begin{array}{c}\text { Nilai } \\
\text { Tertinggi }\end{array}$ \\
\hline Eksperimen & 25 & 80,67 & 102,546 & 67 & 100 \\
Kontrol & 25 & 59,7 & 119,68 & 58 & 83 \\
\hline
\end{tabular}

Berdasarkan Tabel 1 terlihat bahwa nilai rata-rata kelas eksperimen sebesar 80,67, sedangkan kelas kontrol menghasilkan rata-rata 59,7. Secara deskriptif terlihat data skor post-test kelas eksperimen berbeda dengan skor post-test kelas kontrol. Berdasarkan nilai rata-rata, maka kemampuan komunikasi matematis siswa pada kelas yang pembelajarannya menggunakan model PBI lebih tinggi dibanding kelas dengan pembelajaran langsung. Uji Independent $t$ dua sampel digunakan untuk menguji mengetahui perbedaan kemampuan komunikasi matematis siswa yang diberikan model PBI dan model langsung, apakah kemampuan komunikasi matematis kelas eksperimen lebih baik daripada kelas kontrol yang disajikan pada Tabel 2 .

Tabel 2. Hasil Perhitungan Uji Independent $T$ dua sampel

\begin{tabular}{lccccc}
\hline Kelompok & $\begin{array}{c}\text { Jumlah } \\
\text { Siswa }\end{array}$ & $\begin{array}{c}\text { Rata- } \\
\text { rata }\end{array}$ & $\boldsymbol{T}_{\text {hitung }}$ & $\boldsymbol{T}_{\text {tabel }}$ & Kesimpulan \\
\hline $\begin{array}{l}\text { Eksperimen } \\
\text { Kontrol }\end{array}$ & 25 & 80,67 & 7,08 & 2,01 & $\begin{array}{c}\text { Terdapat Perbedaan } \\
\text { kemampuan komunikasi } \\
\text { matematis }\end{array}$ \\
\hline
\end{tabular}

Pada Tabel 2 dapat dilihat hasil perhitungan uji- $t$ dua sampel independen. Karena $t_{\text {hitung }} \geq t_{\text {tabel }}$ yaitu $7,08 \geq 2,01$, maka H0 ditolak dan Ha diterima sehingga dapat disimpulkan terdapat perbedaan kemampuan komunikasi matematis antara siswa kelas eksperimen dengan kelas kontrol. Hal ini serupa dengan pernyataan Marsinia dan Rahmi (2018) yang menyatakan bahwa kemampuan siswa yang mendapat model pembelajaran PBI jauh lebih baik daripada siswa yang memperoleh pembelajaran langsung.

Selanjutnya, dilakukan uji besar pengaruh model PBI terhadap kemampuan komunikasi matematis siswa. Untuk mengetahui besar pengaruh model PBI terhadap kemampuan komunikasi matematis siswa, maka digunakan rumus Effect Size. Adapun hasil perhitungan Effect Size dapat dilihat pada Tabel 3 .

Tabel 3. Hasil Perhitungan Effect Size

\begin{tabular}{lcccc}
\hline \multicolumn{1}{c}{ Kelompok } & $\begin{array}{c}\text { Rata- } \\
\text { rata }\end{array}$ & $\begin{array}{c}\text { Standar Deviasi } \\
\text { Kontrol }\end{array}$ & Effect Size & Keterangan \\
\hline Eksperimen & 80,67 & 10,94 & 1,97 & $\begin{array}{c}\text { Besar pengaruh } \\
\text { model PBI } \\
\text { Kontrol }\end{array}$ \\
\hline
\end{tabular}

Pada Tabel 3 dapat dilihat bahwa hasil perhitungan Effect Size $=1,97$ dengan kriteria besar karena ES berada pada $\mathrm{ES} \geq 0,8$. Hal ini berarti model PBI memberikan pengaruh yang besar terhadap kemampuan komunikasi matematis siswa. Hal ini sejalan dengan pernyataan Husnidar (2014) yang menyatakan bahwa PBI melatih siswa menyusun sendiri pengetahuannya, mengembangkan keterampilan pemecahan masalah, mandiri serta meningkatkan kepercayaan diri. Selain itu, dengan pemberian masalah otentik, siswa dapat menggunakan dan mengingat lebih lama konsep yang diajarkan sehingga tidak hanya sekedar menghafal konsep saja dengan kata lain model PBI dapat meningkatkan kemampuan komunikasi matematis siswa.

\section{Kemampuan Berpikir Kreatif}

Data hasil belajar diperoleh dari kelas eksperimen dan kelas kontrol yang masing-masing kelas berjumlah 25 siswa. Kemudian kedua kelas diberikan soal post-test. Hasil post-test dihitung dan diperoleh hasil yang disajikan pada Tabel 4. 
Tabel 4. Data Hasil Post-Test Kemampuan Berpikir Kreatif

\begin{tabular}{cccccc}
\hline $\begin{array}{c}\text { Kelompok } \\
\text { kelas }\end{array}$ & $\boldsymbol{N}$ & $\overline{\boldsymbol{X}}$ & $\boldsymbol{S}^{\mathbf{2}}$ & $\begin{array}{c}\text { Nilai } \\
\text { Terendah }\end{array}$ & $\begin{array}{c}\text { Nilai } \\
\text { Tertinggi }\end{array}$ \\
\hline Eksperimen & 25 & 73,60 & 179,56 & 100 & 47 \\
Kontrol & 25 & 42,13 & 144,57 & 60 & 27 \\
\hline
\end{tabular}

Pada Tabel 4 diperoleh bahwa nilai rata-rata kelas eksperimen sebesar 73,60 sedangkan kelas kontrol menghasilkan rata-rata 42,13 . Secara deskriptif terlihat data skor post-test kelas eksperimen berbeda dengan skor post-test kelas kontrol. Berdasarkan nilai rata-rata, maka kemampuan berpikir kreatif siswa pada kelas yang pembelajarannya menggunakan model PBI lebih tinggi dibanding kelas dengan pembelajaran langsung. Uji Independent $t$ dua sampel digunakan untuk mengetahui perbedaan kemampuan berpikir kreatif siswa yang diberikan model PBI dan model langsung, apakah kemampuan berpikir kreatif kelas eksperimen lebih baik daripada kelas kontrol.

Tabel 5. Hasil Perhitungan Uji Independent $\mathrm{T}$ dua sampel

\begin{tabular}{lccccc}
\hline Kelompok & $\begin{array}{c}\text { Jumlah } \\
\text { Siswa }\end{array}$ & $\begin{array}{c}\text { Rata- } \\
\text { rata }\end{array}$ & $\boldsymbol{T}_{\text {hitung }}$ & $\boldsymbol{T}_{\text {tabel }}$ & Kesimpulan \\
\hline Eksperimen & 25 & 80,67 & 8,84 & 2,01 & Terdapat Perbedaan \\
Kontrol & 25 & 59,7 & & & kemampuan berpikir kreatif \\
\hline
\end{tabular}

Berdasarkan Tabel 5 dapat dilihat hasil perhitungan uji t-dua sampel independen. Karena $t_{\text {hitung }} \geq t_{\text {tabel }}$ yaitu 8,84 > 2,01 maka terdapat perbedaan kemampuan berpikir kreatif antara siswa kelas eksperimen dengan kelas kontrol. Hal ini serupa dengan pernyataan Marsinia dan Rahmi (2018) yang menyatakan bahwa kemampuan berpikir kreatif pada siswa yang mendapat model pembelajaran PBI jauh lebih baik daripada siswa yang memperoleh pembelajaran langsung.

Selanjutnya dilakukan uji besar pengaruh model PBI terhadap kemampuan berpikir kreatif siswa. Untuk mengetahui besar pengaruh model PBI terhadap kemampuan berpikir kreatif siswa, maka digunakan rumus Effect Size. Adapun hasil perhitungan Effect Size dapat dilihat pada Tabel 6.

Tabel 6. Hasil Perhitungan Effect Size

\begin{tabular}{lcccc}
\hline Kelompok & $\begin{array}{c}\text { Rata- } \\
\text { rata }\end{array}$ & $\begin{array}{c}\text { Standar Deviasi } \\
\text { Kontrol }\end{array}$ & Effect Size & Keterangan \\
\hline Eksperimen & 73,60 & 12,02 & 2,61 & $\begin{array}{c}\text { Besar pengaruh } \\
\text { model PBI }\end{array}$ \\
Kontrol & 42,13 & 13,02 & & \\
\hline
\end{tabular}

Pada Tabel 6 dapat dilihat bahwa hasil perhitungan Effect Size $=2,61$ dengan kriteria besar karena ES berada pada $\mathrm{ES} \geq 0,8$. Hal ini berarti model PBI memberikan pengaruh yang besar terhadap kemampuan berpikir kreatif siswa. Hasil tersebut sejalan dengan pendapat Pratiwi dan Rizal (2020) bahwa PBI adalah kegiatan pembelajaran dengan masalah yang berpusat pada siswa dengan memberikan masalah sekitar siswa tersebut. Yang dimana model pembelajaran PBI mempengaruhi belajar siswa dalam meningkatkan kemampuan berpikir kreatif siswa.

\section{Motivasi Belajar}

Angket motivasi belajar siswa merupakan angket yang diberikan kepada siswa kelas eksperimen untuk mengetahui motivasi masing-masing siswa setelah diberi perlakuan pembelajaran dengan menggunakan model pembelajaran PBI pada materi Bangun Ruang Sisi Datar. Hasil perhitungan ratarata angket motivasi belajar siswa pada pernyataan positif dapat dilihat pada Tabel 7.

Tabel 7. Rekapitulasi Angket Motivasi Siswa Keseluruhan

\begin{tabular}{ccc}
\hline Rata-rata pernyataan positif & Rata-rata pernyataan negatif & Kriteria \\
\hline 3,818 & 3,697 & Tinggi \\
\hline \multicolumn{2}{c}{ Rata-rata total $=3,764$} & Tinggi \\
\hline
\end{tabular}


Pada Tabel 7 dapat dilihat bahwa rata-rata motivasi belajar siswa untuk pernyataan positif dan negatif pada semua indikator berada pada kriteria tinggi dengan jumlah siswa 25 orang menghasilkan rata-rata keseluruhan siswa adalah 3,764 dengan kriteria tinggi karena berada pada kisaran, $3,4<\mathrm{x}^{-} \leq 4,2$. Oleh itu dapat dikatakan motivasi belajar siswa tinggi melalu model pembelajaran PBI pada materi Bangun Ruang Sisi Datar.

Hal ini sejalan dengan penelitian Fatwa, Septian, \& Inayah (2019) yang menyimpulkan bahwa pembelajaran yang dilakukan dengan model PBI dimana siswa lebih banyak terlibat aktif dalam menemukan rumus-rumus yang ada pada pembelajaran, sehingga akan berpengaruh pada kemampuan literasi matematis siswa dalam mengaitkan siswa kepada bidang ilmu matematika lain, maupun dunia nyata.

\section{KESIMPULAN}

Berdasarkan pengujian hipotesis dan hasil penelitian di SMP Negeri 1 Singkawang dapat disimpulkan bahwa terdapat perbedaan kemampuan komunikasi matematis dan kemampuan berpikir kreatif antara kelas yang diberikan model PBI dan kelas yang diberikan model pembelajaran langsung, yang dimana kemampuan komunikasi matematis dan kemampuan berpikir kreatif yang diberikan model PBI lebih baik daripada model pembelajaran berlangsung. Model PBI memberikan pengaruh yang besar terhadap kemampuan komunikasi matematis dan kemampuan berpikir kreatif siswa. Motivasi belajar siswa tergolong tinggi pada pembelajaran menggunakan model PBI.

\section{DAFTAR PUSTAKA}

Arif, A., \& Herlina, H. (2018). Penerapan Pendekatan Problem Based Instruction (PBI) Berorientasi Model Pembelajaran Think Pair-Share (TPS) dalam Upaya Meningkatkan Motivasi dan Hasil Belajar Mahasiswa pada Mata Kuliah Evolusi. In Prosiding Seminar Nasional SIMBIOSIS, 3.

Fatwa, V. C., Septian, A., \& Inayah, S. (2019). Kemampuan Literasi Matematis Siswa melalui Model Pembelajaran Problem Based Instruction. Mosharafa: Jurnal Pendidikan Matematika, 8(3), 389-398.

Firman, Mariyam, \& Wahyuni, R. (2020). Penerapan Model Pembelajaran Group Investigation Untuk Meningkatkan Kemampuan Berpikir Kreatif Matematis Siswa Pada Materi Operasi Hitung Bentuk Aljabar Kelas VIII SMP. JPMI (Jurnal Pendidikan Matematika Indonesia), 5(2), 7986.

Habibah, L. (2016). Peningkatan Kemampuan Komunikasi Siswa Melalui Pendekatan Problem Based Learning (PBL) terhadap Siswa MTs N Kelas VII. Jurnal Pembelajaran dan Matematika Sigma (JPMS), 2(1), 46-51.

Husnidar. (2014). Penerapan model pembelajaranberbasis masalah untuk meningkatkankemampuan berfikir kritis siswa dan disposisi matematis siswa. Jurnal Didaktik Matematika, 1(1), 71-82.

Jayanti, M., \& Wiratomo, Y. (2017). Perancangan Media Siap UN Matematika SMP Berbasis Android. SAP (Susunan Artikel Pendidikan), 2(1), 22-32. https://doi.org/10.30998/sap.v2i1.1722

Marsinia, W., \& Rahmi, D. (2018). Pengaruh Penerapan Model Pembelajaran Problem Based Instruction (PBI) terhadap Kemampuan Berpikir Kreatif Matematis berdasarkan Kemandirian Belajar Siswa Sekolah Menengah Atas. JURING (Journal for Research in Mathematics Learning), 1(2), 153-160.

Noviarti, Utami, C., \& Prihatiningtyas, N. C. (2020). Hubungan Motivasi Belajar Matematika Dengan Kemampuan Numerik Siswa pada Materi Aljabar. JPMI (Jurnal Pendidikan Matematika Indonesia), 5(2), 92-99.

Novriansyah, F., Harlin, H., \& Syofii, I. (2018). Perbedaan Model Problem Based Instruction (PBI) dengan Model Pembelajaran Langsung pada Mata Pelajaran Pemeliharaan Kelistrikan Kendaraan Ringan Kelas XI di SMK Negeri 2 Palembang. Jurnal Pendidikan Teknik Mesin, $5(2), 125-132$. 


\section{VARIABE Variabel Vol. 4 No. 2 \\ (October 2021). Page: 46-52}

Pratiwi, A. A., \& Rizal, F. (2020). Pengaruh Model Pembelajaran Problem Based Instruction Berbasis Collaboration, Communication, Creativity and Critical Thinking terhadap Hasil Belajar Rangkaian Elektonika. INVOTEK: Jurnal Inovasi Vokasional Dan Teknologi, 20(1), 61-68.

Saputra, H. (2018). Kemampuan Berpikir Kreatif Matematis. In Prosiding Seminar Nasional Penelitian, pp. 521-526.

Sefrinal, S. (2019). Pengaruh Pendekatan Problem Based Learning terhadap Kemampuan Berpikir Kreatif Matematis Siswa Kelas X SMA Negeri 1 Sutera. Jurnal Kepemimpinan dan Pengurusan Sekolah, 4(2), 157-168. https://doi.org/10.34125/kp.v4i2.417.

Soraya, S., Rosmaiyadi, R., \& Wahyuni, R. (2021). Pengaruh Model Pembelajaran SQ3R terhadap Kemampuan Komunikasi Matematis Siswa SMP pada Materi Pola Bilangan. JPMI (Jurnal Pendidikan Matematika Indonesia), 6(1), 28-34.

Sugiyono. (2017). Metode Penelitian Kuantitatif, Kualitatif, dan R\&D. Bandung: CV. Alfabeta. 